SOCIAL PHILOSOPHY AND PHILOSOPHY OF HISTORY

UDC 141.21:165.742

DOI: https://doi.org/10.30839/2072-7941.2019.177701

\title{
THE AMBIVALENT NATURE OF OPTIMISM IN THE CONTEXT OF THE CONCEPT OF NEW HUMANISM
}

\author{
(C) VODOP'YANOV, PAVEL \\ Belarusian State Technical University (Minsk, Belarus) \\ E-mail: pva1940@bk.ru ORCID iD: 0000-0002-7881-4114 \\ (C) SIDORENKO, IRINA \\ Belarusian State University (Minsk, Belarus) \\ E-mail: iri_na2000@rambler.ru ORCID iD: 0000-0001-7792-0102
}

\begin{abstract}
The purpose of this study is to discover the ambivalent nature of the idea of optiman in the concept of the problem of new humanism. The essence of ecological and anthropological crises is the subject of analysis by the authors of this article. The given problematics is revealed through the reference to the analysis of the idea of optiman. Methodology of research are general lofical research methods, method of historical and philosophical reconstruction, method of comparative analysis, method of system analysis.

The scientific novelty of the research is the synthetic approach to solving the anthropological crisis, taking into account both ecological, biological and existential problems. Anthropological crisis has shown not only existential, but also biosocial problems of human existence and preservation of his biological bases. In this context, the idea of the possibility of purposeful intervention in human genetics and creation of an optiman or a superman dominates. The concept of «optiman» implies an attempt of harmonization of human innings, but not the replacement of natural givenness with something else. The «control over evolution» in such transcription assumes conscious work of many generations on creation of an opriman. However, technocratic attitudes of modern society demarcate this sense, emphasizing that the nature of an individual is determined not so much by the natural capabilities of the organism as by the technological achievements of modern civilization, which allow overcoming the natural barriers. The ambivalent nature of the idea of optiman appropriately constituents the search for new meanings in the notions of human nature. In this article two approaches to understanding optimen: transhumanism and existentialism are considered. The first approach is based on the positions of the expediency of transformation of human nature by technology, the second understands the ideal of the human as his ability to self-overcome.
\end{abstract}

Conclusions. It is noted that transhumanism without recourse to the existentials of human existence can lead to increased alienation of a person and his technical suppression. The authors of the article conclude that a new humanism should be established.

Key words: optiman, anthropological crisis, alienation, transhumanism, existentialism, humanism.

Introduction. The modern global era is often referred to as the era of bifurcation, in which the previous trajectory loses stability, the danger of global disasters increases dramatically, and it determines the need of choose a new path of development. At the same time, the strategic choice facing humanity is associated with significant difficulties 
in choosing further development due to the exacerbation of global problems that threaten the near future.

At present, two possible ways of choosing the future are emerging: either to radically change the existing worldview of mankind in relation to nature, to follow in the direction of achieving the environmentally safe path of development, or to follow the path of further accumulation of wealth through intensive economic growth, leading to the destruction and degradation of the environment.

An analysis of the reality in developed countries shows that, unfortunately, the second option, aimed at maintaining and achieving high levels of consumption, is often preferred. This is confirmed by the formidable outlines of the global environmental crisis, which is manifesting itself in increased environmental pollution, ozone depletion, floods, hurricanes and other dangerous symptoms that have affected most countries of the world. That is why the formation of new worldview orientations, based on the approval of new forms of interaction between society and nature, is one of the key tasks of modern environmental policy. The need to change the existing worldview orientations is inextricably linked with the need to ensure stable socioeconomic development while maintaining a favorable environment and rational use of natural resources.

This value orientation, clearly stated in the strategy of sustainable development adopted by the international community in 1992, was aimed at limiting economic growth and industrial development in general.
However, as the further development of society has shown, despite the formidable outlines of the environmental crisis, there have been no radical changes in the world in terms of concrete implementation of the strategy and changes in the worldview: the gap in consumption between poor and rich countries is growing rapidly, interethnic conflicts in the international arena are becoming more and more intense, military actions in many regions of the world are flare up and military actions are flared up, with all the acuteness of the formidable outlines of the economic crisis, which has affected virtually everything with These and other dangerous trends pose a real threat to the immediate future of humankind and are primarily linked to the loss of traditional moral values, the spiritual degradation of human beings and the fragile belief in stable future.

The way out of such difficulties is not so much connected with the solution of socio-economic, ecological or even geopolitical problems, but with the necessity of radical change of people's consciousness, worldview and moral values.

The main part. The environmental crisis is closely linked to the anthropological crisis. The main characteristics of the anthropological crisis are the following: loss of confidence in the future, which is expressed in the competition of future models; looseness of the world as the loss of immutable laws; general leveling and victory of an «onedimensional» person; increasing dependence of a person on the 
machine; «cyberization» of the human body; development of opportunities for information and technological management of the human consciousness; creation of artificial needs; escalation of violence, etc. In general, it is lawful to define the current situation as a triumph of a person's destructive nature.

The problem of the «anthropological crisis» is reflected not only in the emphasis on the problem of the «duality» of human nature, but also in the dichotomy of true and not authentic existence: the problem of the alienation of true existence is manifested in the powerlessness, in «spirit of vengeance», envy and anger; in the impossibility of implementing existentialism in the projection of reality, in the mechanization of the world, in the loss of the feeling of home and the meaning of existence in not authentic communication.

Anthropological crisis has shown not only existential, but also biosocial problems of human existence and preservation of his biological bases. In this context, the idea of the possibility of purposeful intervention in human genetics and creation of an optiman or a superman dominates. The concept of «optiman» implies an attempt of harmonization of human innings, but not the replacement of natural givenness with something else. The «control over evolution» in such transcription assumes conscious work of many generations on creation of an opriman. However, technocratic attitudes of modern society demarcate this sense, emphasizing that the nature of an individual is determined not so much by the natural capabilities of the organism as by the technological achievements of modern civilization, which allow overcoming the natural barriers.

The ambivalent nature of the idea of optiman appropriately constituents the search for new meanings in the notions of human nature. Discussions on the boundaries of permissible interference in human nature and control over evolution unfold in the space of existentialism and transhumanism ideas.

Philosophy

by

German existentialism

(K. Jaspers, M. Heidegger) emphasizes the idea of the openness of a human existence, its projectivity. It is possible to achieve the completeness and authenticity of existence only through selfovercoming, self-projecting out of alienation. According to the idea of K. Jaspers, existence, as a type of existence, refers not to the "world», but to transcendence. Alienation from transcendence deprives a person of both true existence and genuine communication.

Existence cannot be defined, but its realization as a special kind of reality is possible in communication with other existences. In a borderline situation a person realizes his own finitude, historicity, thereby making a «leap» from the world of everyday life. Only after realizating the finitude of existence, a person can see the connection with transcendent. Existence is like despair. It would seem that transcendence provides the initial stability of human existence. However, K. Jaspers, on the contrary, sharpened the problem of contradictions of existential integrity. Of all living things, only a man knows 
about his limb. As an incompleteness of his finitude becomes for him a greater test than what is revealed in the simple cognition of the finite. Man has lost of being, from which grow a task and opportunity: he discovers that he is in a desperate position, but so that he is made a persistent demand to rise through freedom.

M. Heidegger also problematized the real existence of man (Dasein). Describing the phenomenal difference between horror and fear, he defined the first as being in front of an absolute Nothing, before a complete loss of orientation and support, before the total end of all possibilities. Horror raises the question of the integrity of his being before Dasein, revealing death as his own possibility to be himself. Death is a potential threat to make all possibilities unfeasible. As M. Heidegger noted, death as an opportunity blocks the ways of self-realization. Thus, the awareness of death, vanity of any project justifies the historicity of existence, incompleteness of each of its motives, alienation of man. Alienation is rightfully interpreted as a «not-authentic» understandin of being, as a «not-authentic» existence.

The means of overcoming alienation consists in temporality and historicity as the real existence is a being-to-death as only in the face of death of people can become free, i.e. can recognize and choose among possibilities such which appear to be unattainable for death. In everyday being Dasein is divided into existential fragments, so the gaining of integrity for him like as his own death. According to M. Heidegger's idea, such existence in «being to death» distinguishes Dasein from the safe anonymity of being among «people» (das Man). Ordinary knowledge about death is irrelevant to Dasein, as in everyday life death appears indirectly as death of «Other». In not- authentic existence death is as an event, as pure possibility in the face of the finality to be itself, completely excludes, there is an avoidance of death as the fact of existence.

«Horror» and «being to death» only point to the existence of Dasein as an integrity. Having realized the totality of alienation and selfexclusion, a person decides on the choice of possibility. This «determination» is set not through temporality, but through historicity, as temporality expresses only finitude, under historicality is understood the extension of existence from birth to death, life as a history to be solved. Horror has pointed to the existential and ontological integrity of Dasein, the expression of which in M. Heidegger becomes «care» (Sorge). At the same time, «care» means mutual attribution of the meaning of being and temporal structures of existence. It is inextricably connected with Dasein, its limb and its historicity: the temporary structure of "care» is the structure of being in the world $[1, \mathrm{p}$. 329].

Since, according to M. Heidegger's idea, the meaning of being is equal to the understanding of being, i.e. Dasein's self-engineering, the «care» expresses the integrity of Dasein's being. Dasein 's possibility to become himself is a temporary phenomenon of «future» as «coming» for himself. 
Determination and anticipation of death make Dasein create the future according to his capabilities. Becoming oneself in the fashion of the future shows that Dasein has already «become» someone, that it is already actual and therefore historical. However, the past always comes back to the future. Historicality is precisely what makes up the temporary phenomenon of the past, which emerges from the horizon of the future. Such unity of time is the specificity of Dasein. Only being a historical, time-conscious person can overcome violence in the form of selfexclusion, alienation from others. Dasein has no end, where it simply stops, but it is existential of course. Dasein, as long as it exists, appears at the same time as its own «not yet», its «end» stands before a man in his own being.

Unlike representatives of existentialism, transhumanists (S. Young, N. Bostrom, R. Kurzweil, etc.), note the projectivity of human nature and radicalize the idea of modifying anthropological nature and defend the idea of freedom in the use of new technologies to improve human intelligence, ability to control emotions, etc. [2]. At the same time, it does not focus on the problems of human dehumanization, on the increase of the risk of evolutionary error.

Transhumanists revised the content of the concept of «heredity», concluding that information, including genetic information, can be connected with any material carrier (for example, with «chimera» - the result of interspecific mixing or combination of artificial and natural). Under the humanist slogan «everything to man and everything for man», representatives of transhumanism advocate the idea of complete freedom in the use of new technologies to improve human intellect, ability to control emotions, change genetic parameters and physical capabilities of man. At the same time, the horizon of transformation is determined by the possibility or impossibility of a reproductive «union» with unmodified individuals without taking into account the increasing risk of evolutionary error.

For transhumanism, the improvement of the human being by moving beyond the limits of the way of existence with the help of the artificial intelligence system becomes a goal achieved by means of new technologies. Because of this, human dignity is identified with the capacity for self-transformation, primarily at the biological level, and is not related to the ideas of human self-value.

Therefore, the posthumanist perfection of man proposed by transhumanism does not actually affect such qualities as sympathy, care, temporality, freedom, etc. The paradoxical nature of this approach is that by freeing individuals from natural dependence, transhumanists do not take into account the existence of a more rigid restriction: dependence on technology, technical control, and restrictions on access to information. On the other hand, the question of the purpose of such evolution as self-overcoming remains unanswered; on the contrary, the idea of progress for the sake of progress itself is being actualized. 
The result is the forced alienation a man from the human being, which gives rise to such a phenomenon as the existential feeling of «homelessness» of the human being in the world. According to the idea of $\mathrm{K}$. Jaspers, the technique radically changed the everyday life of man, turned the existence into the action of a technical mechanism. K. Jaspers defined modern existence as mass, focused on the satisfaction of desires and transformation of the world around him. Modern man hopes to find peace not in transcendence, but in the world, which can be changed through technology, and thus try to lead to perfection. However, since man still has limited capabilities and technology also has limits, and not always what he wants to achieve turns out to be a good thing, nowadays there is a «feeling of helplessness and homelessness», or a feeling of emptiness of being. Technocratic civilization with its belief that everything can be calculated and controlled, has carried out a revolution, putting a man in the service of machinization and turning him into a kind of raw material to be purposefully processed [3]. «...He who used to be the substance of the whole and its meaning, now becomes a means» [4, p. 138].

There was a separation of man from his soil; even his house and land are like machines, so they are transient and interchangeable. Now, influencing the nature with the help of machines, a man is not freed from the need to work, but at the same time, he distances his work from nature, does not resist it as a living creature. Labor becomes mechanical, and the more mechanical it is, the less value it has and the more people have to work. Violence by alienation is manifested as alienation from its historicity, so that time for the modern man appears as a symbol of haste, concern for the momentary, the «anger of the day», where everything is counted on the result, but not on the creation and communication.

Following K. Jasper's example, German poet and thinker Franz Jünger noted this problem: having lost his own, essential (Eigentum), i.e. source, continuity with the cultural tradition, a man is included in the total connection of one big machine. The power of technology that simultaneously transforms and destroys. At the same time, the complete automatism of the modern world leads to naked dynamism: «We are facing a dead time. Life is at the service of automatism, which begins to regulate it» $[5$, s. 44$]$. As a result, the technique that violently destroys the human being's existential space leads, first, to the loss of man's redundancy as a prerequisite for the joy of creativity, second, to the oblivion of tradition, his history, and, third, to the «homelessness» of man.

Not-authentic, the lack of concealment of the modern epoch is caused by the illusory belief in the ability of technology to foresee and calculate everything. However, the perfection of technology only seems to be perfect. Therefore, F. Jünger, following the representatives of German existentialism, raised the question of a return to authenticity, or, using his vocabulary, to «new secrecy», which he found in the «wastelands» as an unidentified and 
unnamed space in which there was no violence. The wasteland is beyond the control of man, not burdened by technology, but outside of the power aspirations and violent hierarchy, and therefore appears to be useless for the consumer economy of man. There are no names here, so there is no property, no borders. F. Jünger saw the ideal of a man as a wanderer, bypassing and protecting this sacred source, the space of creative possibilities.

F. Jünger saw an opportunity for a man to overcome violence and «homelessness» in a language, a rhythm that is leveled out in the world of machine noise. So, the return of authentic exsistence he understood as a search for his way to the path of impassability, the road to an untapped space. The real language of tradition becomes the language that reveals its source to the person - on the way back. F. Jünger called it a wasteland. The rhythm of return always sounds, but in order to hear it, it is necessary to give up domination over it, to give it freedom. If a person listens carefully to the rhythm of return, he will be able to go to the source, to the wasteland. That is why $F$. Jünger entrusted the return of the role of the structure of the world in which man discovers himself. However, the return to the «new secret», as noted by the poet and thinker, clearly articulates the task of finding and new reliability (Sicherheit). On this basis, a modern man still needs to earn the trust of space, to become worthy of his message. Whether a man will feel his «homelessness» and therefore «rape» always someone else's space depends on whether he will be able to learn to spare the wasteland and protect it.

Conclusion. Thus, the claim of transhumanism to create an optiman without taking into account the existentialities of human existence is rightfully considered as speculation subordinated to the dream of perfection. In turn, existential philosophy, emphasizing the problems of technical violence against the nature of man, alienation, notauthentic existence of man and his «homelessness» in the modern world, can give the dream of the ideal realizable features.

Therefore, in order to prevent post-humanism from becoming an anti-humanism, it is necessary to supplement it with a conceptual component of existentialism.

It is therefore necessary to establish a new humanism. The new humanism means not only the establishment of true human relations between people, but also respect and care for the preservation of all forms of life, as reflected in the convention on the conservation of biological diversity adopted by the world community.

According to A. Peccei, the new humanism is aimed at significant improvement of human qualities of all inhabitants of the planet and therefore it proposes to make the focus of human attention, the way of existence and way of life, because the fate of the new world order will depend on its qualities and abilities.

A. Peccei believes that the progressive development of man and the parallel improvement of his human qualities will bring a radical revision of human perception of 
himself and man in general, his role and responsibility [6].

The establishment of a new humanism presupposes the need to form new value orientations, motives and regulations of human activity, which is due to the severity of the current environmental situation, the growth of social upheaval in the spiritual, social and political spheres of society $[7 ; 8]$.

Overcoming such dangers is connected with the change of the existing vector of civilization development and its transition to the path of harmonious socio-natural evolution on the basis of the biosphere thinking and a new educational society.

\section{REFERENCES}

1. Heidegger, M. (1997). Being and Time. Per. Bibihina. M., 452.

2. Letov, O. V. (2018). Man and the «superman»: ethical aspects of transgumanism. 1, $19-25$.

3. Sidorenko I. N. (2018). «Homelessness» in the technocratic world // Human Problem in Modern Philosophy of Technology All-Russian Scientific and Practical Conference dedicated to the memory of I.A. Negodaev (Rostov-on-Don, March 29, 2018): Materials and Reports / Editorial: E.E. Nesmeyanov, D.K. Kulikov; Donskoy Tekhn. Rostov n/A: DSTU, 170-174.

4. Jaspers, K. Origins of history and its purpose // Meaning and purpose of history; Per. with him. 2nd edition. M., 1994. C. 28-287.

5. Jünger, F. G.(1949). Die Perfektion der Technik. Maschine und Eigentum. Friedrich G. Jünger. Frankfurt. M., 524.

6. Peccei, A. (1980). Human qualities. M.: Progress, 302.

7. Teslenko, T. V. (2018). Dichotomyia «spirit/intelligence - body» and ìx in the context of philosophy economy: methodology of ambush. Humanities Bulletin of Zaporizhzhe State Engineering Academy, 64, 53-64.

8. Sidorenko S. V. (2019). Digital Technology Developer in the fields of medicine in the minds of «globalization 4.0»: Social and Philosophical Imiri. Humanities Bulletin of Zaporizhzhe State Engineering Academy, 64, 44-55 .

ВОДОП'ЯНОВ П. О. - доктор філософських наук, професор, професор кафедри філософії i права, Білоруський державний технологічний університет, членкореспонедент Національної академії Білорусі (Мінськ, Республіка Білорусь).

E-mail: pva1940@bk.ru ORCID iD: 0000-0002-7881-4114

СИДОРЕНКО I. М. - кандидат філософських наук, доцент, доцент кафедри філософії і методології науки, Білоруський державний університет (Мінськ, Републіка Білорусь)

E-mail: iri_na2000@rambler.ru, ORCID iD: 0000-0001-7792-0102

\section{АМБІВАЛЕНТНА ПРИРОДА ОПТИМІЗМУ У КОНТЕКСТІ КОНЦЕПЦЇ̈ НОВОГО ГУМАНІЗМУ}

Метою даного дослідження є виявленния амбівалентної природи ідеї оптимізму у концепції нового гуманізму. У даній статті аналізується сутність екологічної та антропологічної криз. Методи дослідження: загальнологічні методи дослідження, метод історико-філософської реконструкції, метод компаративного аналізу, метод системного аналізу.

Наукова новизна дослідження - у синтетичному підході до вирішення проблеми антропологічної кризи, яка враховує як екологічну, біологічну, так і екзистенційну 
проблематику. Антропологічна криза вплинула не тільки на екзистенційні, але й на біосоціальні проблеми існування людини і збереженння іiі біологічних основ. У цьому контексті домінує ідея про можливість цілеспрямованого втручання у генетику людини i створення оптимену, чи зверхлюдини. Під концептом «оптимізм» слід розуміти спробу гармонізації людських здібностей, а не заміну природної даності чимось іншим. «Контроль над еволюцією» у такій транскрипції передбачає свідому роботу багатьох поколінь щодо створення оптимену. Проте технократичні установки сучасного суспільства демаркують цей смисл, акцентуючи увагу на тому, що природа індивіда визначається не стільки природними можливостями організму, стільки технологічними досягненнями сучасної цивілізації, що дозволяють подолати природні бар'єри. Амбівалентний характер ідеї оптимізму відповідним чином конституює і пошук нових смислів в уявленнях про людську природу. У статті розглядаються два підходи до осмислння оптимізму: трансгуманізм та екзистенціалізм. Перший підхід базується на позиціях доцільності перетворення природи людини через посередництвао техніки, другий під ідеалом людини розуміє його здатність до самовизначення.

Висновки. Відмічається, що трансгуманізм без звернення до екзистенціалів людського буття може привести до посиленння відчуження людини і до технічного тиску. Тому автори статті приходять до висновку, що необхідно встановити новий гуманізми.

Ключові слова: оптимізм, антропологічна криза, відчуження, трансгуманізм, екзистенціалізм, гуманізм.

ВОДОПЬЯНОВ П. А. - доктор философских наук, профессор, профессор кафедры философии и права, Белорусского государственного технологического университета, член-корреспондент Национальной академии наук Беларуси (Минск, Республика Беларусь).

E-mail: pva1940@bk.ru ORCID iD: 0000-0002-7881-4114

СИДОРЕНКО И. Н. - кандидат философских наук, доцент, доцент кафедры философии и методологии науки Белорусского государственного университета (Минск, Республика Беларусь).

E-mail: iri_na2000@rambler.ru ORCID iD : 0000-0001-7792-0102

\section{АМБИВАЛЕНТНАЯ ПРИРОДА ОПТИМИЗМА В КОНТЕКСТЕ КОНЦЕПЦИИ НОВОГО ГУМАНИЗМА}

Целью данного исследования является выявление амбивалентной природы идеи оптимизма в концепции проблемы нового гуманизма. В данной статье анализируется сущность экологического и антропологического кризисов. Методы исследования: общелогические методы исследования, метод историко-философской реконструкции, метод компаративного анализа, метод системного анализа.

Научная новизна исследования заключается в синтетическом подходе к решению проблемы антропологического кризиса, учитывающем как экологическую, биологическую, так и экзистенциальную проблематику. Антропологический кризис проявил не только экзистенциальные, но и биосоциальные проблемы существования человека и сохранения его биологических основ. В этом контексте доминирует идея о возможности целенаправленного вмешательства в генетику человека и создания оптимена, или сверхчеловека. Концепт «оптимизм» подразумевает попытку гармонизации человеческих задатков, а не замену природной данности чем-то иным.

«Контроль над эволюцией» в такой транскрипции предполагает сознательную работу многих поколений по созданию оптимена. Однако технократические установки современного общества демаркируют этот смысл, делая акцент на том, что природа индивида определяется не столько естественными возможностями организма, сколько 
технологическими достижениями современной цивилизации, позволяющими преодолеть природные барьеры. Амбивалентный характер идеи оптимизма соответствующим образом конституирует и поиск новых смыслов в представлениях о человеческой природе. В статье рассматриваются два подхода к осмыслению оптимизма: трансгуманизм и экзистенциализм. Первый подход стоит на позициях целесообразности преобразования природы человека посредством техники, второй понимает под идеалом человека его способность к самопреодолению.

Выводы. Отмечается, что трансгуманизм без обращения к экзистенциалам человеческого бытия может привести к усилению отчуждения человека и его технического подавления. Поэтому авторы статьи приходят к выводу, что необходимо установить новый гуманизм.

Ключевые слова: оптимизм, антропологический кризис, отчуждение, трансгуманизм, экзистенциализм, гуманизм.

Стаття рекомендована до публікаиії д.філософ.н., проф. О. П. Кивлюк Київ, Україна) Надійшла до редколегї: 10.06.2019 Прийнята до друку: 25.06.2019 